\title{
DEPRESSION AND ITS DETERMINANTS IN AN URBAN ELDERLY OF MAHARASHTRA: A CROSS- SECTIONAL STUDY
}

\author{
Swapnil R. Jain ${ }^{1}$, Alka C. Kaware2, Radhey B. K³, Shabana Shaikh', Mohan K. Doibale ${ }^{5}$, Madhuri P. Mathurkar6, Sandesh V. Kamble7, \\ Sandeep Babar 8 \\ ${ }^{1}$ Assistant Professor, Department of Community Medicine, Government Medical College, Miraj, Maharashtra, India. \\ ${ }^{2}$ Assistant Professor, Department of Community Medicine, Indira Gandhi Medical College, Nagpur, Maharashtra, India. \\ 3Junior Resident, Department of Community Medicine, Government Medical College, Miraj, Maharashtra, India. \\ ${ }^{4}$ Specialty Medical Officer, Department of Community Medicine, Topiwala National Medical College and BYL Nair Hospital, Mumbai \\ Central, Maharashtra, India. \\ ${ }_{5}^{5}$ Professor and HOD, Department of Community Medicine, Government Medical College, Aurangabad, Maharashtra, India. \\ 6Junior Resident, Department of Community Medicine, Government Medical College, Miraj, Maharashtra, India. \\ 7Junior Resident, Department of Community Medicine, Government Medical College, Miraj, Maharashtra, India. \\ 8Junior Resident, Department of Community Medicine, Government Medical College, Miraj, Maharashtra, India.
}

\section{ABSTRACT}

\section{BACKGROUND}

Growth in the elderly population has led to an increase in age related diseases and mainly depression affecting quality of life. Depression in old age is an emerging public health problem leading to morbidity and disability worldwide.

\section{AIMS}

To assess the prevalence of depression in elderly using the Geriatric Depression Scale (GDS) and to study the variables affecting depression in them.

\section{SETTINGS AND DESIGN}

A community-based descriptive Cross-Sectional Study.

\section{METHODS AND MATERIAL}

Study was conducted in the urban slums, field practice area of Community Medicine attached to a tertiary care hospital. Study period was Jan. 2013-Dec. 2014. Persons aged $\geq 60$ years residing in the urban slums were included. A pre-designed, pre-tested proforma was used to collect information. GDS-15 was used to screen depression.

\section{STATISTICAL ANALYSIS USED}

Data was entered in Microsoft excel and analysed by using frequency, proportion, chi-square test with SPSS 16.

\section{RESULTS}

Prevalence of depression was 48.8\%. Females (63.8\%) were more affected than males (36.2\%). Depression was significantly associated with various variables like age, sex, educational status, occupation, sleep pattern and socioeconomic status.

\section{CONCLUSIONS}

The study presented higher rate of depression among elderly and its interesting association with various socio-demographic variables, which may have important implications for health planning.

\section{KEYWORDS}

Depression, Elderly, Urban, Ageing, Geriatric Depression Scale (GDS), Sleep Pattern.

HOW TO CITE THIS ARTICLE: Jain SR, Kaware AC, Radhey BK, et al. Depression and its determinants in an urban elderly of Maharashtra: a cross-sectional study. J. Evolution Med. Dent. Sci. 2016;5(28):1449-1452, DOI: 10.14260/jemds/2016/340

\section{INTRODUCTION}

The geriatric population is defined as population age 60 years and above. ${ }^{1}$ Elderly people are more prone to various emotional and psychological changes.

Financial or Other, Competing Interest: None.

Submission 16-02-2016, Peer Review 12-03-2016,

Acceptance 18-03-2016, Published 07-04-2016.

Corresponding Author:

Dr. Swapnil R. Jain,

Assistant Professor, Department of Community Medicine,

Government Medical College, Miraj,

Miraj Pandurpur Highway-Miraj-416410

Maharashtra,

India.

E-mail: sjvicky85@gmail.com

DOI: $10.14260 /$ jemds $/ 2016 / 340$
Various typical reactions are observed which include withdrawal, apathy, loss of self-esteem, depression and feeling of loneliness. ${ }^{2}$ Among all psychiatric disorders in geriatric population, depression is most common of all. It is demonstrated that it is on fourth rank among all global burdens of diseases. The global burden disease study showed that it will come to second number by the year 2020 in developing countries. It is predicted to increase more than 690 million. $^{3}$

Studies of late life depression has found that prevalence of depression is higher in elderly as compared to other age groups. ${ }^{4}$ According to $\mathrm{WHO}$, factors increasing depression risk in older adults include genetic susceptibility, chronic disease and disability, pain, frustration with limitations in Activities of Daily Living (ADL), personality traits (Dependent, anxious or avoidant), adverse life events 
(Separation, divorce, bereavement, poverty, social isolation) and lack of adequate social support. Many studies have demonstrated a relationship between depression and various socioeconomic variables such as advanced age, low education, poverty and manual occupation.

Thus, an older adult patient suffering from depression often has a combination of psychological, physical and social needs. ${ }^{5}$ Economic hardship with continued low standard of living affects the body and the mind. Retirement, change in housing, illness or death of spouse greatly affect the physical wellbeing of the aged person. ${ }^{6}$ Elderly patients with depression are more prone for cardiovascular, lung diseases and are less likely to adhere to their diet, exercise and medications as compared to elderly patients without depression. ${ }^{7}$ Therefore, early diagnosis and treatment remains the mainstay to reduce the burden of this disease. Keeping above in mind, present study was conducted to find prevalence of depression among elderly and to study associated factors with it.

\section{MATERIAL AND METHODS}

The present study was carried out at the Urban field practice area and was part of thesis conducted under Department of Community Medicine attached to tertiary care hospital. Study period was Jan 2013 to Dec 2014. Ethical approval was taken from Institutional Ethical Committee. It was communitybased cross-sectional study. A Short Form Geriatric Depression Scale (GDS). ${ }^{8}$ consisting of 15 questions was used. Prevalence of depression among elderly using Geriatric Depression Scale (GDS)-15 in various studies conducted in different part of India was in range of $42 \%-53 \% .1,5,9-15$ So the lowest prevalence, i.e. $42 \%$ was taken into consideration for sample size estimation. By adopting the following formula for sample size calculation. ${ }^{16}$ i.e. $\mathrm{n}=\mathrm{z}^{2} \mathrm{pq} / \mathrm{l}^{2}$ at $95 \%$ confidence interval with an allowable error of $10 \%$, sample size was 600 .

Thus, total 600 elderly subjects were studied. The total 11 wards under field practice area of urban health centre of a Medical College in a city of Maharashtra were enlisted. As wards-sampling units vary considerably in population size, Probability Proportional to Size (PPS) sampling method. ${ }^{17}$ was used, study population of the age group 60 years and above enumerated for each ward by using voter (Electoral) list of 2012. Physical activity of the study subjects was defined by the criteria recommended by WHO.18 Data was collected by semi-structured questionnaire. Data entry and statistical analyses used SPSS version 16. Frequency distributions were calculated for all variables. The chi-square test was used to test significance of associations between independent variables and depression with the threshold for significance set at $\mathrm{p}=0.05$.

\section{RESULTS}

According to Table 1, out of 600 subjects, majority 307 (51.2\%) had GDS score between $0-4$ revealing that they were not in depression, 168 (28\%) had GDS score between 5-8 suggesting mild depression, 118 (19.7\%) had GDS score between 9-11 suggesting moderate depression, 7 (1.1\%) had GDS score between 12-15 suggesting severe depression. Among 262 males, majority 156 (59.5\%) were not screened positive for depression, while only $2(0.8 \%)$ were having GDS score between 12 and 15 suggesting severe depression.
Among 338 females, majority 151 (44.7\%) were not screened positive for depression, while only 5 (1.5\%) were having GDS score between 12 and 15 suggesting severe depression.

Depression was significantly associated with various variables like age, sex, educational status, occupation, sleep pattern and socioeconomic status $(\mathrm{p}<0.05)$ [Table 2]. Out of 600 subjects, 293 i.e. $48.8 \%$ were screened positive for depression. Among positive subjects, majority $34.8 \%$ were in age group of $65-69$ years, while only $6.5 \%$ were in age group of $75-79$ years; $36.2 \%$ were males and $63.8 \%$ were females. Among positive subjects, majority (48.1\%) were Buddhist, while $0.7 \%$ belonged to others. Among subjects screened positive for depression majority $61.8 \%$ were married, while only $0.3 \%$ each were unmarried and separated.

In accordance with Table 3, among positive subjects, majority $51.9 \%$ were illiterate, while only $3.1 \%$ were graduated and above. Among positive subjects, majority $75.4 \%$ were unemployed, while only $2.4 \%$ were professionals. Among positive subjects, majority $47.1 \%$ were from three generation family, while only $23.2 \%$ were from joint family. Majority of subjects with depression had disturbed sleep pattern (89.1\%). Out of 293 study subjects who were screened positive for depression, majority 145 $(49.5 \%)$ belonged to socio-economic class $\mathrm{V}$, while only $1.7 \%$ were in class I.

\begin{tabular}{|c|c|c|c|}
\hline $\begin{array}{c}\text { Depression as Per } \\
\text { GDS 15 Score }\end{array}$ & Male & Female & Total \\
\hline Absent (0-4) & $156(59.5)$ & $151(44.7)$ & $307(51.2)$ \\
\hline Mild (5-8) & $65(24.8)$ & $103(30.5)$ & $168(28)$ \\
\hline Moderate (9-11) & $39(14.9)$ & $79(23.3)$ & $118(19.7)$ \\
\hline Severe (12-15) & $2(0.8)$ & $5(1.5)$ & $7(1.1)$ \\
\hline Total & $\mathbf{2 6 2 ( 1 0 0 )}$ & $\mathbf{3 3 8 ( 1 0 0 )}$ & $\mathbf{6 0 0}(100)$ \\
\hline $\begin{array}{r}\text { Table 1: Distribution of Depression among Study Subjects according } \\
\text { to Geriatric Depression Scale (GDS) - 15 Score }\end{array}$
\end{tabular}

(Figures in Parenthesis Denote Percentages)

\begin{tabular}{|c|c|c|c|c|}
\hline $\begin{array}{c}\text { Socio- } \\
\text { Demographic } \\
\text { Variables }\end{array}$ & Category & Depression & $\begin{array}{l}\text { Chi- } \\
\text { Square }\end{array}$ & $P$ value \\
\hline \multirow{5}{*}{ Age (In years) } & $60-64$ & $72(24.6)$ & \multirow{5}{*}{75.52} & \multirow{5}{*}{$<0.0001$} \\
\hline & $65-69$ & 102(34.8) & & \\
\hline & $70-74$ & $58(19.8)$ & & \\
\hline & $75-79$ & $19(6.5)$ & & \\
\hline & $>80$ & $42(14.3)$ & & \\
\hline \multirow{2}{*}{ Sex } & Male & $106(36.2)$ & \multirow{2}{*}{13.057} & \multirow{2}{*}{$<0.0001$} \\
\hline & Female & 187(63.8) & & \\
\hline \multirow{4}{*}{ Religion } & Buddhist & 141(48.1) & \multirow{4}{*}{2.263} & \multirow{4}{*}{0.520} \\
\hline & Hindu & $55(18.8)$ & & \\
\hline & Muslim & $95(32.4)$ & & \\
\hline & Others* & $2(0.7)$ & & \\
\hline \multirow{5}{*}{ Marital status } & Married & $181(61.8)$ & \multirow{5}{*}{9.141} & \multirow{5}{*}{0.06} \\
\hline & Unmarried & $1(0.3)$ & & \\
\hline & $\begin{array}{c}\text { Widow/Widow } \\
\text { er }\end{array}$ & $107(36.6)$ & & \\
\hline & Divorced & $3(1.0)$ & & \\
\hline & Separated & $1(0.3)$ & & \\
\hline \multirow{3}{*}{$\begin{array}{l}\text { Type of } \\
\text { family }\end{array}$} & Nuclear & $87(29.7)$ & \multirow[b]{3}{*}{0.366} & \multirow[b]{3}{*}{0.833} \\
\hline & Joint & $68(23.2)$ & & \\
\hline & $\begin{array}{c}\text { Three } \\
\text { Generation }\end{array}$ & $138(47.1)$ & & \\
\hline Total & & $293(100)$ & & \\
\hline \multicolumn{5}{|c|}{$\begin{array}{c}\text { Table 2: Association of Depression among Study Subjects with Socio- } \\
\text { Demographic Variables }\end{array}$} \\
\hline
\end{tabular}

(Figures in Parenthesis Denote Percentages)

$\left\{{ }^{*}\right.$ Others- Jain, Sikh, Christian\} 


\begin{tabular}{|c|c|c|c|c|}
\hline $\begin{array}{c}\text { Socio- } \\
\text { Demographic } \\
\text { Variables } \\
\end{array}$ & Category & Depression & $\begin{array}{c}\text { Chi- } \\
\text { Square }\end{array}$ & $\begin{array}{c}P \\
\text { value }\end{array}$ \\
\hline \multirow{6}{*}{$\begin{array}{l}\text { Educational } \\
\text { status }\end{array}$} & Illiterate & $152(51.9)$ & \multirow{6}{*}{12.24} & \multirow{6}{*}{0.032} \\
\hline & Primary & $56(19.1)$ & & \\
\hline & Middle & $37(12.6)$ & & \\
\hline & Secondary & $19(6.5)$ & & \\
\hline & $\begin{array}{c}\text { Higher } \\
\text { Secondary }\end{array}$ & $20(6.8)$ & & \\
\hline & $\begin{array}{c}\text { Graduate } \\
\text { and above }\end{array}$ & $9(3.1)$ & & \\
\hline \multirow{5}{*}{ Occupation } & Unemployed & $221(75.4)$ & \multirow{5}{*}{$\begin{array}{c}10.09 \\
,\end{array}$} & \multirow{5}{*}{0.039} \\
\hline & Unskilled & $45(15.4)$ & & \\
\hline & Semi-skilled & $12(4.1)$ & & \\
\hline & Skilled & $8(2.7)$ & & \\
\hline & Professionals & $7(2.4)$ & & \\
\hline \multirow{3}{*}{$\begin{array}{l}\text { Physical } \\
\text { activity }\end{array}$} & Sedentary & $244(83.3)$ & \multirow{3}{*}{2.81} & \multirow{3}{*}{0.245} \\
\hline & Moderate & $39(13.3)$ & & \\
\hline & Heavy & $10(3.4)$ & & \\
\hline \multirow{2}{*}{ Sleep pattern } & Normal & $32(10.9)$ & \multirow[t]{2}{*}{---- } & \multirow{2}{*}{$<0.0001$} \\
\hline & Disturbed & 261(89.1) & & \\
\hline \multirow{5}{*}{$\begin{array}{c}\text { Socioeconomic } \\
\text { status }\end{array}$} & I & $5(1.7)$ & \multirow{5}{*}{9.8} & \multirow{5}{*}{0.044} \\
\hline & II & $21(7.2)$ & & \\
\hline & III & $37(12.6)$ & & \\
\hline & IV & $85(29.0)$ & & \\
\hline & $\mathrm{V}$ & $145(49.5)$ & & \\
\hline Total & & $293(100)$ & & \\
\hline $\begin{array}{r}\text { Table 3: } \\
w i \\
\end{array}$ & $\begin{array}{l}\text { ciation of De } \\
\text { cio-Demogr }\end{array}$ & $\begin{array}{l}\text { ssion among } \\
\text { ic Variables }\end{array}$ & $\begin{array}{l}\text { tudy } \\
\text { Contd }\end{array}$ & \\
\hline
\end{tabular}

(Figures in Parenthesis Denote Percentages)

\section{DISCUSSION}

In the present study, out of 600 subjects, majority (51.2\%) were not in depression, while (48.8\%) were screened positive for depression. Among 600 subjects (28\%) had mild, (19.7\%) moderate, $(1.1 \%)$ had severe depression [Table 1] Similarly, Jain RK et al. (2007). $\cdot{ }^{9}$ (45.9\%), Dasgupta A et al. (2014).15 (46.9\%), while Nair SS et al. (2013).19 (32.4\%) Arumugam B et al. (2013).10 found that prevalence of mild depression was $38.9 \%$, severe (41.1\%), while $20 \%$ were not depressed. Sanjay TV et al (2014). ${ }^{20}$ found that 36 (36\%) were found to depressed. Among 36 who were depressed, 21 $(58.3 \%)$ were in moderate and $15(41.7 \%)$ were in severe depression. The difference in the prevalence with this study might be due to the difference in sample size.

According to Table 2, no significant association was found between depression and age in studies conducted by Jain RK et al. (2007). ${ }^{9}$ and Sati P et al. (2013). ${ }^{5}$ which is contradicting findings in our study, where it was significant. With regard to sex, significant association was found in current study and females were more depressed as compared to males. Findings were consistent with study by Maulik $\mathrm{S}$ et al. (2012). ${ }^{11}$ but Jain RK et al. (2007). ${ }^{9}$ found no significant association. Higher proportion of depression in females could be due to reason that majority of them had sedentary lifestyle being housewife. As far as marital status was concerned, no significant findings were obtained which corroborates with previous study conducted by Maulik S et al. (2012). ${ }^{11}$ Stanley A et al.21 Arun R et al.22 Xie LQ et al.23 But Jain RK et al. (2007). ${ }^{9}$ and Sati $P$ et al. (2013). ${ }^{5}$ found depression to be significantly associated with marital status. This may be due to the small sample size in this study as compared to the other studies.

Illiterates were found to be more depressed in this study [Table 3], which is quite similar to findings of Maulik S et al. (2012). ${ }^{11}$, Stanley A et al. ${ }^{21}$ Ramchandra et al. ${ }^{24}(\mathrm{p}<0.01)$. Thus supports the fact that illiteracy leads to unproductive life and cause greater difficulty in getting jobs, leading to depression, while Sati P et al. (2013). ${ }^{5}$ found no significant association between depression and educational status. Jain RK et al. (2007). 9 found depression to be significant associated with occupation. Maulik S et al. (2012).11 found that at home people were at greater risk of depression than those who were still working. These findings were similar to our study.

Depression was found to be significantly associated with sleep pattern in elderly with higher proportion in elderly with disturbed sleep pattern, well documented in previous study by Jain RK et al. (2007). ${ }^{9}$ Subjects in low socioeconomic group were found to be more depressed, suggesting association between socio-economic status and depression. Low income makes them more dependent on other for financial support making them more prone for depression. Similarly, Jain RK et al. (2007). ${ }^{9}$ and Xie LQ et al. ${ }^{23}$ found depression to be significantly associated with socioeconomic status. In contrast, Sati P et al. (2013). ${ }^{5}$ found no significant association. Strengths and limitations: The GDS is not a substitute for a diagnostic interview by mental health professionals.

It is a useful screening tool in the clinical setting to facilitate assessment of depression in older adults, especially when baseline measurements are compared to subsequent scores. It does not assess for suicidality. ${ }^{25}$ The sample was drawn from one limited geographic area. So, the results cannot be generalized. Because of the cross-sectional design, this study had a limited extrapolative value. As the study was carried during 2013-2014, but the available elderly list was of 2012 which might have missed those who were on the border of 60 years at the time of the study.

\section{CONCLUSION}

Around half of the elderly were screened positive for depression. Slum areas lack health personnel. There are high chances to ignore the most prevalent psychiatric disorders like depression because of various reasons like unaware of prevalence rate, vague presentation of cases with multiple physical symptoms, negligence to find the accurate diagnosis while providing health care services. Mental health care and psychological rehabilitation should be part of health care of the elderly. The need of the hour is to set up geriatric wards and geriatric OPD having specialized professionals with psychiatric and medical social workers along with subsidized health care services.

\section{RECOMMENDATIONS}

The government agencies should carry out special surveys to identify the vulnerable aged and the deprivations suffered by them. There is growing need for good quality geriatric health care service at the primary level and it should be based on the "felt needs." Regular screening, health check-ups to lessen morbidity should be promoted. Involvement of NGO and voluntary organizations are equally important. Finally, the increasing population of aged has called for the need of training and further research and larger community based study in Geriatrics and Gerontology. 


\section{REFERENCES}

1. Elango S. A study of health and health related social problems in the geriatric population in a rural area of Tamil Nadu. Indian J Public Health 1998;42(1):7-8.

2. Tyagi I, Goel A. Factors affecting clothing choices of elderly females. Indian Journal of Gerontology 2013;27(2):307-19.

3. Javed S, Mustafa N. Prevalence of depression in various demographic variables among elderly. IJHSR 2013;2:224.

4. Ernst C. Epidemiology of depression in late life. Curr Opin Psych 1997;10(2):107-12.

5. Sinha SP, Shrivastava SR, Ramasamy J, et al. Depression in an older adult rural population in India. MEDICC Review 2013;15(4):41-4.

6. Gurav RB, Kartikeyan S. Problems of geriatric population in an urban area. Bombay Hosp J 2002;44(1):47-51.

7. Pracheth R, Mayur SS, Chowti JV. Geriatric depression scale: a tool to assess depression in elderly. Int J Med Sci Public Health 2013;2(1):31-5.

8. Yesavage JA, Brink TL, Rose TL, et al. Development and validation of a geriatric depression screening scale: a preliminary report. J Psychiatr Res 1983;17(1):37-49. Available

at http://www.stanford.edu/ yesavage/GDS.html.

[Accesed online on Nov 2012].

9. Jain RK, Aras RY. Depression in geriatric population in urban slums of Mumbai. Indian J of Public Health 2007;51(2):112-3.

10. Arumugam B, Nagalingam S, Nivetha R. Geriatric depression among rural and urban slum community in chennai-a cross sectional study. Journal of evolution of Medical and Dental sciences 2013;2(7):795-801.

11. Maulik S, Dasgupta A. Depression and its determinants in the rural elderly of West Bengal-a cross sectional study. IJBMR 2012;3:1299-302.

12. Reddy NB, Pallavi M, Nagarjuna N, et al. Psychological morbidity status among the rural geriatric population of Tamil Nadu, India: a cross-sectional study. Indian J Psychol Med 2012;34(3):227-31.

13. Naveen KD, Sudhakar TP. Prevalence of cognitive impairment and depression among elderly patients attending the medicine outpatient of a tertiary care hospital in South India. International Journal of Research in Medical Sciences 2013;1(4):359-64.
14. Swarnalatha N. Prevalence of depression among the rural elderly in chittoor district Andhra Pradesh. J Clin Diagn Res 2013;7(7):1356-60.

15. Dasgupta A, Mukhopadhyay M, Das S, et al. Are our elderly really depressed?: a cross sectional study on depression among geriatric population in a slum of Kolkata. IJHSR 2014;4(6):25-30.

16. Abramson JH, Abramson ZH. Survey methods in community medicine: epidemiological research, program evaluation, clinical trials. Elsevier Limited 1999; $5^{\text {th }}$ edition:102.

17. Steps in applying Probability Proportional to Size (PPS) and calculating. Basic Probability Weights [Online]. [Cited on 18 Jan 2013]; Available from:

URL:http://www.who.int/tb/advisory_bodies.

18. World Health Organization: energy protein requirements. reports of joint FAO/WHO Adhoc Expert Committee, WHO TRS No. 522, 1973;25-6.

19. Nair SS, Hiremath S, Nair SS. Depression among geriatrics: prevalence and associated factors. Ijcrr 2013;5(8):110-12.

20. Sanjay TV, Jahnavi R, Gangaboraiah B, et al. Prevalence and factors influencing depression among elderly living in the urban poor locality of Bangalore city. Int J Health Allied Sci 2014;3(2):105-9.

21. Stanley A, Samuel M, Himmelparb, et al. Prevalence of depression and its correlates in older adults. American journal of epidemiology 2001;11:22-3.

22. Arun R, Kutty VR, Ravindran S. Prevalence of and correlates of depressive symptoms among inmates of old age home in kottayam, kerela, India. Indian journal of psychiatry 1999;18(2):152-7.

23. Xie LQ, Zhang JF, Peng T, et al. Prevalance and related influencing factors on depressive symptoms for empty nest elderly living in the rural area of yongzhou china. Arch Gerontl geriatric 2010;50(1):24-9.

24. Ramchandra V, Sarada MM, Arunagiri S. Socio cultural factors in late onset depression. Indian journal of psychiatry 1982;24(3):268-73.

25. Kurlowicz L. The geriatric depression scale (GDS). Geriatric Nursing 2007;4:192-9. 